\title{
Geomorphological Study of Yelahanka watershed, Bangalore rural district, Karnataka, India
}

\author{
Shivanna S. ${ }^{1}$ And Vyshnavi D.R. ${ }^{2}$ \\ ${ }^{1}$ Associate Professor, Dept. of Civil Engineering, Sir M Visvesvaraya Institute of \\ Technology, International Airport Road, Bangalore, Karnataka, India Pincode-562 157 \\ ${ }^{2}$ Assistant Professor, Dept. of Civil Engineering, Sir M Visvesvaraya Institute of Technology, \\ International Airport Road, Bangalore, Karnataka, India Pincode-562 157
}

\begin{abstract}
The present study area is part of Arkavathi river basin. Geo-morphological study has been carried out to understand the geo-hydrological conditions of the Yelahanka watershed. Remote sensing and Geographic information system was used for the assessment of linear, aerial and relief of the study area. Different quantitative morphological parameters like number of streams, stream frequency, stream length, bifurcation ratio etc., of the watershed reflect its hydro-geological behavior and useful when quantified in evaluating geohydrological reponse of the study area. The Yelahanka watershed obeys the Hortons law of relating linear and aerial aspects. GIS study has revealed the relationship between lithology, structure and morphological characters of the watershed.
\end{abstract}

Keywords: Geomorphology, Rainfall, Drainage, Watershed, RS and GIS.

\section{Introduction}

Quantitative morphometric analysis of any watershed or river basin reflects its geo-hydrological behavior and is therefore useful in evaluating hydrogeological responses of the basin. Yalahanka watershed has been studied to quantify the geomorphological characteristics that will reveal its geographic behavior The study area exhibits the dendritic drainage pattern that produces moderate to nil flood intensity. In order to know and asses the quantity of water available for utilization to a variety of needs a systematic hydro-geological study is essential. In this contest a systematic geomorphological study has

been carried out and results are presented in this paper.

\section{Aim and Objectives}

The main aim and objective of the present study is to find out the stream development in a drainage to calculate number of stream orders, basin area of the drainage, drainage density to prepare DEM (digital elevation map), drainage, soil, landuse and land cover maps for further studies. Details of these studies will reveal the presence of potential zones of groundwater occurrence in the basin. .

\section{Study Area}

Yelahanka watershed is a part of Arkavathi river basin. The study area is bounded by latitude $13^{\circ} 06^{\prime}$ to $13^{\circ} 40^{\prime} \mathrm{N}$ and longitude $77^{\circ} 35^{\prime}$ to $77^{\circ} 44^{\prime} \mathrm{E}$ at an elevation of 915 metres from the Mean Sea Level (MSL). The Yelahanka lake is $14 \mathrm{kms}$ from the city centre in the north Bangalore and is very close to NH-7 (Bangalore - Hyderabad National Highway). This lake is man-made and has a catchment area of 300 acres. The main source of water is rainfall accumulated in the lake from the surrounding area including villages. The lake is often referred as Yelahanka Doddakere. as it is providing drinking water and irrigation needs to the part of the Bangalore city. The watershed falls in the semi-arid and tropical climate characterized by moderate to hot weather. The normal annual average rainfall is $914 \mathrm{~mm}$. The watershed is comprised of an undulatary terrain with a maximum elevation of $950 \mathrm{~m}$ and a minimum elevation of $903 \mathrm{~m}$.

\section{Methodology}

Geo-morphological study of Yalahanka watershed is carried out by using the digital data of IRS 1C,1D of both LISS III and Pan merged. These satellite images have been geo-referenced and merged using the image processing software ERDAS IMAGINE (Version 8.5). The merged data has been used to 
prepare drainage map of the study area. The drainage has been delineated using merged satellite data of Geo-coded CC Banda 2,3 \& 4 on 1: 50,000 scale and using Survey of India Toposheets as reference for tracing the boundary and drainage of the watershed. The linear measurements have been carried out by using a digital plainimeter and elevation within the watershed has been taken from the toposheets.

\section{Geology of the Area}

Geologically the Yelahanka watershed is predominantly underlined by the granites and gneisses with pockets of schistose rocks and migmatites of Archean age. These rocks are popularly designated as hard rocks. The gneisses in the study area are often found to be intruded by basic dykes, pegmatites and aplitic veins as xeno-lithic patches. The occurrence of charnockites has been noticed in the south-western regions and there are some elongated bodies of amphibolites and green schists in the central part of the study area. These hard rocks are fractured and fissured and also have undergone extensive weathering. It is also noticed at certain locations chemical decomposition in the plains and valleys resulting in weathered mantle ranging with a thickness of 10 to 30 meters forming the most potential groundwater reservoir in the study area. Laterites of Paleocene age seen at places as cappings on the gneisses in the northen parts of the study area. Allunium occurs as local patches along the stream course and nullahs with a limited extant.

\section{Morphometric Analysis}

Morphomeric analysis has been carried out to understand the geometry of the drainage, drainage network, texture and relief aspects of the watershed. Many researchers have emphasized the controls of lithological, structural and tectonic features on drainage network development $[1,2,3,4,5,6,7,9,10]$. The details of geo-morphological parameters of Yelahanka watershed have been shown in Table 1 and 2. based on the study.

Table:1 Results of Geo-morphological analysis of the Yelahanka watershed.

\begin{tabular}{|c|c|c|c|}
\hline $\begin{array}{c}\text { Stream } \\
\text { order }\end{array}$ & $\begin{array}{c}\text { No. of } \\
\text { streams } \\
\mathbf{( N}_{\mathbf{U})}\end{array}$ & $\begin{array}{c}\text { Bifurcation } \\
\text { ratio }\end{array}$ & $\begin{array}{c}\text { Total length of } \\
\text { streams }\left(\mathbf{L}_{\mathbf{U}} \text { in }\right. \\
\mathbf{~ k m})\end{array}$ \\
\hline I & 90 & 2.90 & 54.800 \\
\hline II & 31 & 4.40 & 23.367 \\
\hline III & 7 & 7.00 & 15.269 \\
\hline IV & 1 & - & 8.544 \\
\hline
\end{tabular}

Table:2 Results of the Morphometric analysis of the Yelahanka watershed.

\begin{tabular}{|c|c|c|}
\hline $\begin{array}{c}\text { Sl. } \\
\text { No. }\end{array}$ & Parameter & Value \\
\hline 1 & Basin Area $\left(\mathrm{km}^{2}\right)$ & 53.0000 \\
\hline 2 & Perimeter $(\mathrm{km})$ & 30.9551 \\
\hline 3 & Basin order & 4.0000 \\
\hline 4 & Drainage density $\left(\mathrm{D}_{\mathrm{d}}\right)\left(\mathrm{km} / \mathrm{km}^{2}\right)$ & 1.9241 \\
\hline 5 & Stream frequency $\left(\mathrm{F}_{\mathrm{f}}\right)\left(\mathrm{km}^{-2}\right)$ & 2.4339 \\
\hline 6 & Relief ratio $\left(\mathrm{R}_{\mathrm{h}}\right)$ & 0.0108 \\
\hline 7 & Basin length $(\mathrm{km})$ & 101.9800 \\
\hline 8 & Mean Bifurcation ratio & 4.7666 \\
\hline 9 & Form factor $\left(\mathrm{R}_{\mathrm{f}}\right)$ & 0.5096 \\
\hline 10 & Circularity ratio $\left(\mathrm{R}_{\mathrm{c}}\right)$ & 0.8031 \\
\hline 11 & Elongation ratio $\left(\mathrm{R}_{\mathrm{e}}\right)$ & 0.8649 \\
\hline 12 & Length of overland flow $\left(\mathrm{L}_{\mathrm{g}}\right)$ & 0.5300 \\
\hline 13 & Compactness coefficient & 0.8802 \\
\hline
\end{tabular}

\subsection{Drainage Pattern}

Analysis of drainage is also known as fluval morphometry, which provides information regarding the factors which generally control in the development of a drainage. Morphomertic analysis means the measurement of shape of the watershed and length of the streams. On the basis of projections of the systems to a horizontal plane, the linear properties such as a length, area, arrangements etc have been calculated. This method of study is known as planimetric study which means measurements in a single plane.

The study area exhibits dendritic pattern of drainage (Fig.1) which is typically of massive and hard crystalline rocks. The watershed exhibits $4^{\text {th }}$ order of drainage network and the bifurcation ratio is 4.8 which is normal according to Horton [2] and it indicated that the basin is in the mature stage. According to Strahler [11] the value of the bifurcation ratio is higher than 5 indicates structural control over the drainage network. In the present study the bifurcation ratio value of 4.8 does not reflect structural control of lineament zones in the drainage. But, as the value of 4.8 is nearer to 5 , it indicates that some portion of the major strams are controlled by lineaments. 


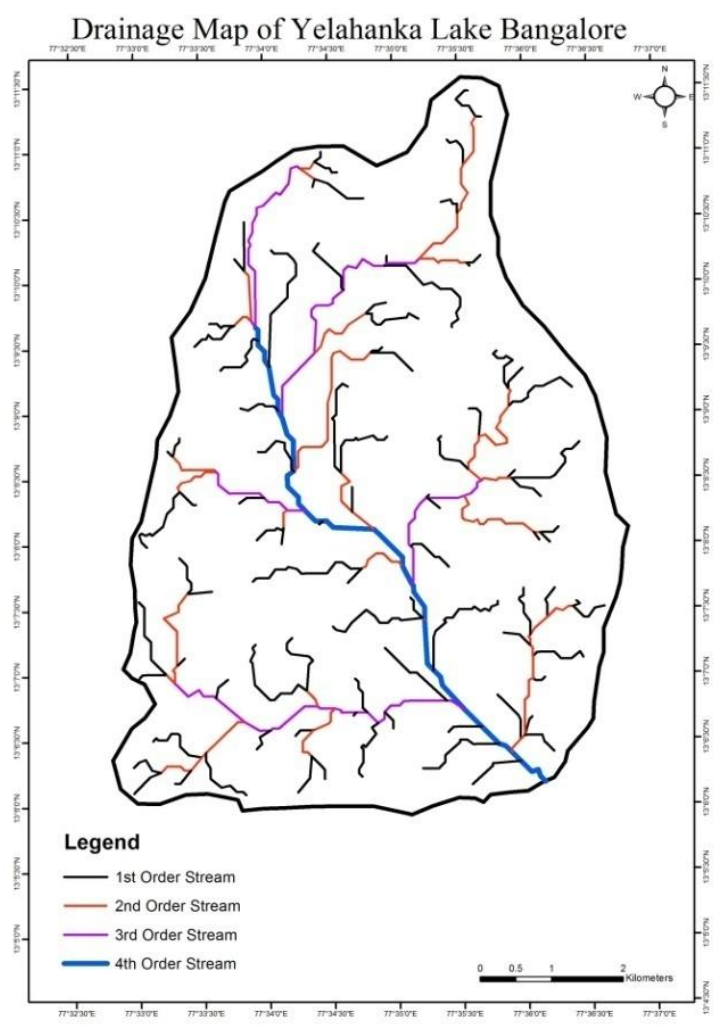

Figure 1: Drainage map of Yelahanka watershed

\subsection{Stream Order}

The designation of the stream order is the first step in drainage basin/watershed analysis and is based on the hierarchic resulting of streams. In the present investigation ranking of streams has been carried out based on the method proposed by Strahler [12]. It is observed in the preent study that the maximum number of streams are in the lower order. It is also noticed that there is a decrease in the stream frequency as the stream order increases. Horton [3] stated that the number of streams of each order forms an inverse geometric sequence with other higher stream order numbers. The slope analysis has also been done to prepare digital elevation map for the study area (Fig. 2).

\subsection{Stream Length}

Stream length is one of the most significant hydrological feature of the watershed/basin as it reveals the surface runoff characteristics. Streams of relatively smaller length have characteristic area with larger slopes and linear textures. In the present study the average stream length was determined by random sampling technique. The mean stream length and other related parameters are given in Table 1. Horton [2] defined the length ratio $(\mathrm{Rl})$ as the ratio of the mean length of channel segment of a given order to that of lower order. The slope gives the length ratio, which is 2.49 for the study area.

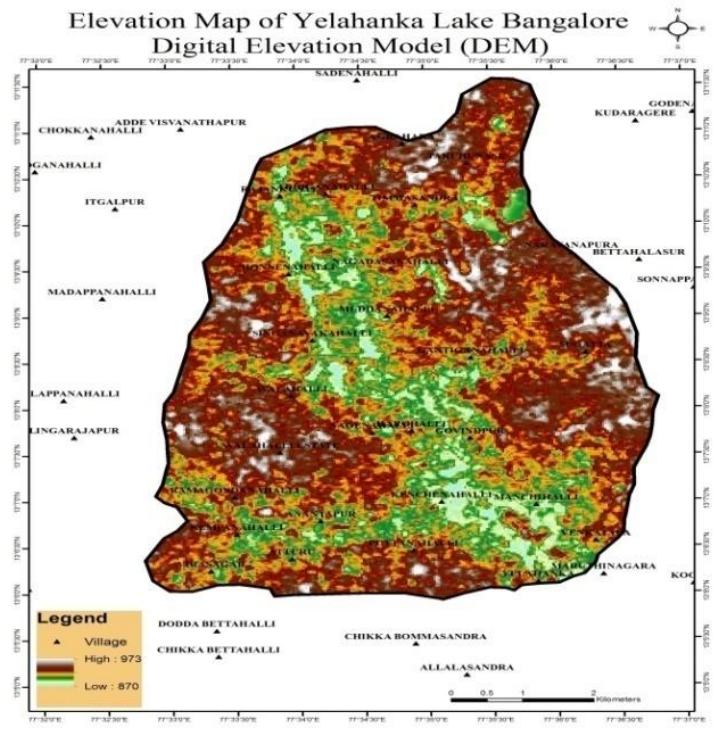

Figure 2: Digital Elevation Map (DEM) of Yelahanka watershed.

\subsection{Drainage Density}

Horton [2] introduced the drainage density (Dd) and it is an expression to indicate the closeness of spacing of streams.It is the total channels segment length cumulated for all orders within the basin to the basin area which is expressed in terms of $\mathrm{Km} / \mathrm{Km} 2$. It has been observed from the drainage density measurements made over wide range of geologic and climatic type that a low drainage density is more likely to occur in a region where highly permeable subsoil material under dense vegetation cover with relief. The drainage density of the study area is $1.9241 \mathrm{Km} / \mathrm{Km} 2$ indicating the coarse drainage density. The coarse drainage density generally indicates the basin is roughly permeable and dense vegetation.

\subsection{Stream Frequency}

Stream frequency (Fs) is expressed as the total number of stream segments of all orders per unit area. It exhibits positive correlation with drainage density in the watershed. indicating an increase in stream population with respect to increase in drainage density The stream frequency for the study area is 2.4339 .

\subsection{Circularity Ratio}

Circularity ratio $(\mathrm{Rc})$ is the ratio of an area of a basin to the circle having the same circumference as the perimeter of the basin. It is generally influenced by the length and frequency of the streams, geological structures, land use and land cover, climate and slope of the basin. The circularity ration ( $\mathrm{Rc}$ ) to the present study is 0.8031 and it indicates that the basin is characterized by moderate 
to low relief. The drainage system seams to be less influenced by structural disturbances,. The high value of circularity ratio shows that the late maturity stage of topography.

\subsection{Elongation Ratio}

Elongation ratio is the ratio of the diameter of circle of the same area as the drainage basin and the maximum length of the basin [8]. Values of elongation ratio $(\mathrm{Re})$ generally vary from 0.6 to 1.0 over a wide variety of climatic and geologic types. Re values can be grouped into three categories namely : (a) circular (greater than 0.9), (b) oval (0.9 to 0.8 ) and (c) less elongated (less than 0.7 ). The $\mathrm{Re}$ values for the present study is 0.8649 indicating moderate to high steep slopes.

\subsection{Landuse and Landcover}

Land use is an important concept consisting of natural resources like soil, water and flora with fauna. The landuse and landcover map of the study area (Figure 3) shows that the area is exhibited by large agricultural land, urban development, water bodies and vegetation.

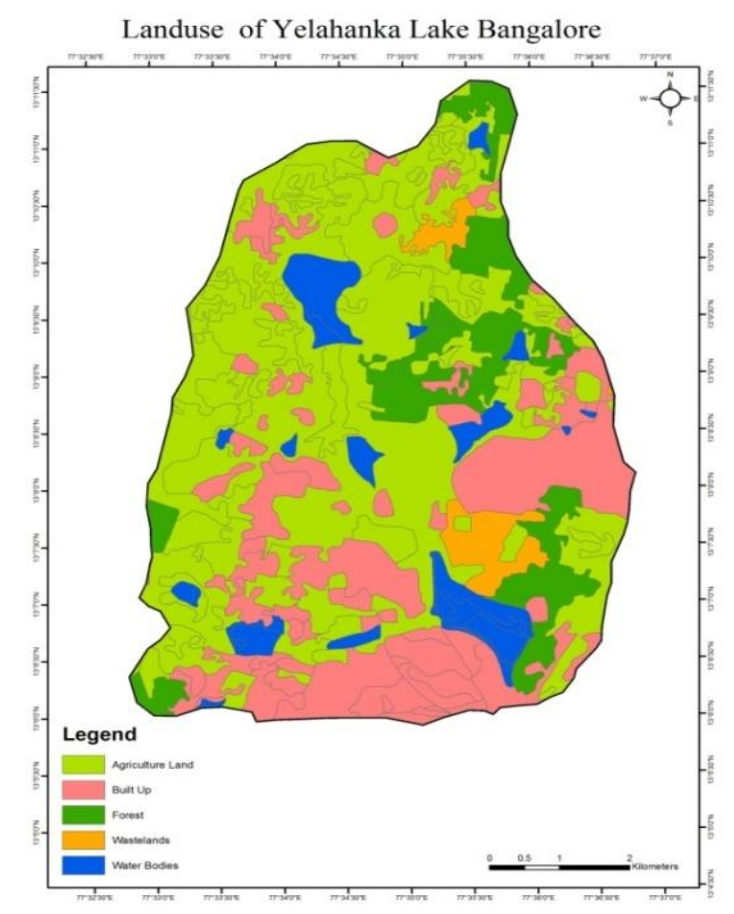

Figure 3: Landuse map of Yelahanka watershed

There will be much impact of climate, soils and vegetation on the land use aspect of any watershed in addition to topographic condition. If the government/private organizations interested to do any developmental activities like formation layouts or housing colonies, industries, roads etc should have perfect understanding of landuse which in turn does not affect the local environment.

\subsection{Soil}

The study area Yelahanka watershed is mainly exhibited by a variety of clayey soils (Clayey soil, gravel with clayey soil, clayey soil with weathered crustations and clayey soil with hard cores. But the large part of the study area is composed of clayey soil and it indicated the basin is underlined by highly fractured and fissured crystalline rocks. The second largest soil type is clayey soil with surface crusting followed by clayey soil with gravels of different sizes ( Figure 4).

Soil Map of Yelahanka Lake Bangalore

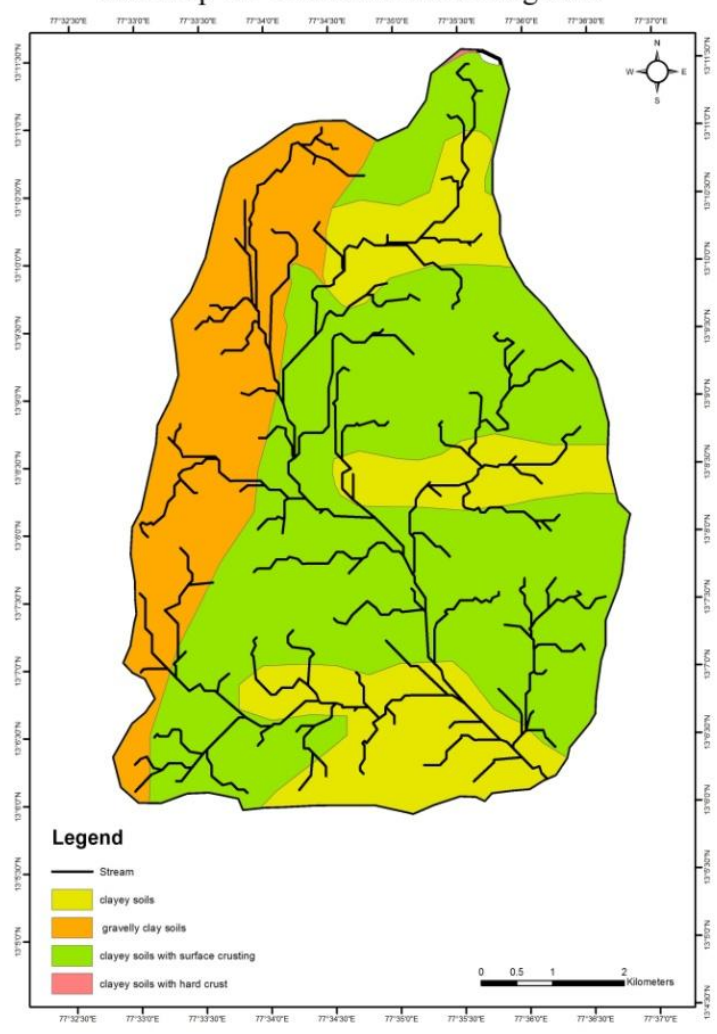

Figure 4: Soil map of Yelahanka watershed.

\section{Conclusion}

Remote sensing anf GIS tools have made more easier for calculating various papmeters of the morphometric study. Based on the present study of the Yelahanka watershed/basin is a $4^{\text {th }}$ order, semicircular, medium to coarse texture matured basin.The watershed/basin obeys the Hortons law [3] in relation to the linear and aerial aspects in the present study. The study area is hard rcok terrain with semi arid climatic condition. The drainage pattern of the study area is mainly controlled by lithology and structures. All the results of the morphometric analysis of the present study are used for planning of flood management, soil erosion 
assessment, water resources management and sustainable development in the basin area.

\section{Acknowledgement}

The authors are thankful to the Principal of Sir MVIT for providing the facilities and also to Dr. Shivakumar Naikal, Scientist, Karnataka State Natural Disaster Monitering Centre, Bangalore for his help in the preparation of the maps.

\section{References}

[1] Chorley R.J. (1969): Drainage basin as the Fundamental Geomorphic Unit., Water, Earth and Man Ed. Metheun and Co.

[2] Horton R.E. (1932): Drainage Basin Characteristics., Trans Am. Geophy. Union, Vol. 13, pp.350-361.

[3] Horton R.E. (1945): Erosional Development of Streams and their Drainage basin: Hydrophysical Approach to Quantitative Morphology. Bull. Geol. Soc. Am. Bull. Vol.56, pp. 275-370.

[4] Leopold L.B. and Miller J.P. ((1956): Ephemeral streams Hydraulic factors and their relation to the Drainage network, USGS Professional Paper 282-A.

[5] Langbein W.B. (1947): Topographic Characteristics of Drainage basin., USGS Water Supply Paper., 968C, pp.125-153.

[6] Miller V.C. (1953): A Qunatitative Geomorphic study of drainage basin characteristics in Clinch Mountain area., Technical Report No.3,
Department Geology, Columbia University, USA.

[7] Narayanaswamy N.K., Shivanna S., Brahmananda, S.B. and Vajrappa, H.C. (2014): A GIS based Morphometric Analysis and Associated Landuse Study of Dakshina Pinakini River Basin, Chikballapur and Bangalore Rural Districts, Karnataka., Journal of Applied Hydrology, Vol.27., No. (1-4)., pp.52-62.

[8] Schumm S.A. (1956): Evolution of Drainage systems and Slopes in Badlands at Perth Ambey, New Jersy., Geol. Soc. Am. Bull. Vol. 67., pp. 597-598, 636-641 and 645-646.

[9] Shivanna S., Anupama V.S., Vyshnavi D.R. and H.P. Mahendra Babu (2017): A GIS based Morphometric Analysis and Associated Landuse Study of Hesaraghatta Watershed, Bangalore District, Karnataka., IJRSI, Vol.4., pp.48-52.

[10] S. Shivanna, D.R. Vyshnavi, S.B. Bramhananda and N.K. Narayanaswamy (2018): Landuse and Landcover Study of Vrishabhavathi River Basin, Karnataka, India., Journal Applied Hydrology., Vol.31, No.1-4., pp.110-118.

[11] Strahler A.N. (1952): Hypsometric Analysis of Erosional Topography., Geol. Soc. Am. Bull., Vol.63, pp.1117-1142.

[12] Strahler A.N. (1968) Quantitative Geomorphology of Drainage basins and Channel networks., Handbook of Applied Hydrology Ed. Chow V.T. Mcgraw Hill Publication. 